\title{
The effect of voltage and time of exposure on surface hardness of resin modified glass ionomer cement
}

Titien Hary Agustantina

Department of Dental Material and Technology Dentistry

Faculty of Dentistry Airlangga University

Surabaya - Indonesia

\begin{abstract}
Light intensity can affect the polymerization of resin-based material therefore it will also affect surface hardness. To compensate reduction of light intensity becaused of the input of low voltage (200 and 210 volt), the exposure time was prolonged to be 40 and 60 seconds. The purpose of this study was to know the effect of voltage and time of exposure of resin modified glass ionomer cement on surface hardness. This study was completed with seventy two samples of resin modified glass ionomer cement 5 mm in diameter and 2 mm in height, exposed by visible light curing for 20, 40, and 60 seconds with voltage input 220, 210 and 200 volt. Micro vickers hardness tester was used to test surface hardness on the upper surface of sample. Two-way ANOVA test and Least Significant Difference (LSD) were used in data analysis with 5\% level of significance. The result showed that lower input (210 and 210 volt) would decrease surface hardness of resin modified glass ionomer cement, longer exposure time (40 and 60 seconds) would increase the surface hardness of resin modified glass ionomer cement. The conclusion is the prolong of exposure time from 20 seconds to 40 and 60 seconds in all voltage input could increase surface hardness of resin modified glass ionomer cement.
\end{abstract}

Key words: voltage, exposure time, resin modified glass ionomer cement, surface hardness

Correspondence: Titien Hary Agustantina, c/o: Bagian Ilmu Material dan Teknologi Kedokteran Gigi, Fakultas Kedokteran Gigi Universitas Airlangga. Jln. Mayjend Prof. Dr. Moestopo 47 Surabaya 60132, Indonesia.

\section{INTRODUCTION}

The tooth restorative material of glass ionomer cement has been widely developed and the development is directed to hybrid form. These materials consist of the component of a glass ionomer cement modified by the inclusion of a small quantity of additional resin which perform an activation to visible light and commonly called resin modified glass ionomer cement. Resin modified glass ionomer cement is developed with the purpose to overcome various problems on the character of glass ionomer cement for example: the sensitivity to humidity and dryness, low strength, bad surface hardness. ${ }^{1,2,3}$ Resin modified glass ionomer cement is immediate hardened after being exposed using visible light so water contamination could be eliminated. Cement which is hardened more quickly might be resistant to water absorption and solubility in water while the acid base reaction would continue. ${ }^{2}$

Resin modified glass ionomer cement is available in the form of powder and liquid. The composition of powder in glass ionomer cement consist of glass particles of calcium fluoroaluminocilicate which could release ion and initiator to enable the curing process chemically or with visible light. ${ }^{1}$ The liquid contain of $5-15 \%$ resin component in the form of hydroxyethyl methacrylate [HEMA] together with less than $1 \%$ polymerisable group and photo initiator which consist of camphoroquinone. ${ }^{2}$ The cement also contains of water and polyacrylic acid or polyacrylic acid with carboxylic group modified with methacrylate and HEMA monomer. The some additional resin and photo initiator in resin modified glass ionomer cement might cause the restorative material harder and quickly hardened (setting). ${ }^{1}$

Resin modified glass ionomer cement could polymerize in two days: dual-cure and tri-cure, ${ }^{1,2,4}$ and it could harden without radiation of visible light through base-acid reaction with radiation of visible light.,

Polymerization of restorative material which performs an activation with visible light really depends on light intensity resulted from visible light curing unit. Electricity which is the energy source of curing is frequently fluctuated in which the voltage would be up and down. Based on the previous study done by using light intensity measurement cure rite visible curing light meter showed input of 200, 220 and 235 volt light intensity: 213.3 ; 354.6; 388.6; $\mathrm{mW} / \mathrm{cm}^{2}$. This condition showed that the change of voltage could alter light intensity resulted from visible light curing unit and possibly would affect the polymerization of resin modified glass ionomer cement. The increase voltage of light exposure until 250 volt will not show significant difference with voltage of light exposure 235 volt or 220 volt toward surface hardness of composite resin. ${ }^{7}$

In the previous study suggested the data that resin modified glass ionomer cement exposed with visible light for 20 seconds with input, 220, 210, and 200 volt would produce surface hardness value: $36.11,25.99$, and 18.96 
VHN. The result of study demonstrated the decrease of voltage directed to visible light curing unit might significantly lower the surface hardness of ionomer cement with decreased level $47.49 \%$.

Visible light curing unit in general is completed with regulator to regulate visible light producing constant results, but various light intensity could occur and the length of effective wave is not always constant. To compensate the decrease of light intensity due to the decrease of voltage input, exposure time of composite restorative resin could done until two or three times longer exposure time than which has been recommended. To add the exposure time is expected to overcome the inadequate polymerization process. ${ }^{1,4}$ The standard of exposure time of polymerized restorative material was 20 seconds. The exposure time which is done longer than 60 seconds tends to be inefficient. $^{5}$

Inadequate visible light curing would produce the polymerization of composite resin uncomplete which could contribute some problems such as decrease of wear resistance: abrasion, atrition, and erosion. ${ }^{4}$ One of the indicators of wear resistance could be detected by measuring surface hardness. ${ }^{5}$

Based on the above background some ideas arise whether the voltage and time of exposure would affect on the surface hardness of resin modified glass ionomer cement. This study is aimed to know the effect of voltege and time of exposure of resin modified glass ionomer cement on surface hardness.

\section{MATERIAL AND METHOD}

The material of the study is resin modified glass ionomer cement Fuji II A 3,5 (GC Japan) and the tools are plastic ring $5 \mathrm{~mm}$ in diameter and $2 \mathrm{~mm}$ height, ${ }^{9}$ visible light curing unit (Litex), voltage regulator, voltmeter, stopwatch, plastic spatula, glass slab, matrix strip, weighing $0.5 \mathrm{~kg}$, micro Vickers hardness tester (Matsuzawa MXT70).

Sample was made as follows: the plastic ring was fixed on glass slab. One spoon powder of resin modified glass ionomer cement was mix with two drops of liquid using plastic spatula on mixing pad. It was done until homogenous for 25 seconds (according to manufacturer recommend). Homogenous material was put into the plastic ring started from the edge part and repeatedly knocked on the table for 5 times. ${ }^{10}$ The upper surface covered with the matrix strip and glass slab was completed with $0.5 \mathrm{~kg}$ weighing for 30 seconds. ${ }^{11}$

The weighing and the glass slab were lifted and the sample surface was exposed with visible light curing unit on matrix strip. In this study there were 9 groups of samples and individual sample groups consisted of 8 samples: group 1: samples with 220 volt input, 20 seconds (control); group 2: samples with 220 volt input, 40 seconds; group 3: samples with 220 volt input, 60 seconds; group 4: samples with 210 volt input, 20 seconds; group 5: samples with
210 volt input, 40 seconds; group 6: samples with 210 volt input, 60 seconds; group 7: samples with 200 volt input, 20 seconds; group 8: samples with 200 volt input, 40 seconds; group 9: samples with 200 volt input, 60 seconds.

After sample exposed with visible light, sample was taken out from the mold and the sample result showed cylinder form and should follow the criteria: porous was invisible, the surface was fine, smooth and parallel.

Surface hardness test was done by measuring the upper surface which was directly exposed by visible light using micro vickers hardness tester completed with $0.5 \mathrm{gr}$ weighing pressure. ${ }^{12}$ Sample was put on the middle part of the table of micro vickers hardness tester and it was activated so that the tip of diamond penetration would leave indentation of sample surface. The result of indentation was observed through the lens of 400 magnifications so that it would show rhomboid form. The diagonal was measured by giving 2 lines to mark both diagonal ends. The read switch was pushed and the data of surface hardness value would appear. Measuring the surface hardness was performed in three different places and the mean would be measured. The data was then tabulated and statistical analysis was done using two-way ANOVA and continued by Least Significant Difference (LSD).

\section{RESULT}

The mean and the standard deviation of surface hardness test of resin modified glass ionomer cement which has been cured for 20,40, and 60 second with voltage input 220, 210, 200 volt could be shown on the table 1 .

Table 1 shows the highest value of surface hardness of resin modified glass ionomer cement is the groups of 60 second exposure with 220 volt input. The lowest value of surface hardness of resin modified glass ionomer cement is the group of 20 second exposure with 200 volt input.

It is necessary to perform data normality test using Kolmogorov Smirnov prior to parametric test. The result of data normality test shows all probability value is higher than $0.05(\mathrm{p}<0.05)$ which means all distribution data is normal therefore it is fulfilled the requirement to perform parametric test using two-way ANOVA.

The result of two-way ANOVA test shows surface hardness was found between time of exposure $(p=0.001)$ and also the different surface hardness was found in interaction between time of exposure and voltage of light exposure. The result of data analysis can also mean that there is significant different resulted from the change of either time or voltage of light exposure of resin modified glass ionomer cement toward surface hardness. The time of exposure is longer resulting the increase of surface hardness of resin modified glass ionomer cement. The decrease of voltage resulting in the decrease of surface hardness of resin modified glass ionomer cement. LSD test is done in order to know the significance of between individual sample group. 
Table 1. The mean and the standard deviation of surface hardness test of resin modified glass ionomer cement which has been cured for 20, 40, and 60 second with voltage input 220, 210, 200 volt (VHN)

\begin{tabular}{ccccccccc}
\hline \multirow{2}{*}{$\begin{array}{c}\text { Electric } \\
\text { Voltage } \\
\text { (volt) }\end{array}$} & $\mathrm{n}$ & \multicolumn{9}{c}{ Second } \\
\cline { 3 - 9 } & & Mean & SD & $\bar{X}$ & SD & $\bar{X}$ & SD \\
\cline { 3 - 9 } & & 36.11 & 0.90 & 38.07 & 0.97 & 38.91 & 1.93 \\
220 & 8 & 25.99 & 2.27 & 27.35 & 2.29 & 28.74 & 1.83 \\
210 & 8 & 18.96 & 2.61 & 26.62 & 1.17 & 27.55 & 1.14 \\
\hline
\end{tabular}

Table 2. The result of LSD test between sample groups of resin modified glass ionomer cement toward surface hardness

\begin{tabular}{|c|c|c|c|c|c|c|c|c|c|}
\hline Group1 & 1 & 2 & 3 & 4 & 5 & 6 & 7 & 8 & 9 \\
\hline 1 & & $0.32 *$ & $0.001 *$ & $0.001 *$ & $0.001 *$ & $0.001 *$ & $0.001 *$ & $0.001 *$ & $0.001 *$ \\
\hline 2 & & & 0.325 & $0.001 *$ & $0.001 *$ & $0.001 *$ & $0.001 *$ & $0.001 *$ & $0.001 *$ \\
\hline 3 & & & & $0.001 *$ & $0.001 *$ & $0.001 *$ & $0.001 *$ & $0.001 *$ & $0.001 *$ \\
\hline 4 & & & & & 0.135 & 0.003 & $0.001 *$ & 0.484 & 0.085 \\
\hline 5 & & & & & & 1.23 & $0.001 *$ & 0.420 & 0.87 \\
\hline 6 & & & & & & & $0.001 *$ & 0.021 & 0.187 \\
\hline 7 & & & & & & & & $0.001 *$ & $0.001 *$ \\
\hline 8 & & & & & & & & & 0.300 \\
\hline 9 & & & & & & & & & \\
\hline
\end{tabular}

Note

$*=$ there is significant difference

Group 1 : Sample with 220 volt input, 20 seconds (control)

Group 2 : Sample with 220 volt input, 40 seconds

Group 3 : Sample with 220 volt input, 60 seconds

Group 4 : Sample with 210 volt input, 20 seconds

Group 5 : Sample with 210 volt input, 40 seconds

Group 6 : Sample with 210 volt input, 60 seconds

Group 7 : Sample with 200 volt input, 20 seconds

Group 8 : Sample with 200 volt input, 40 seconds

Group 9 : Sample with 200 volt input, 60 seconds

The result of LSD test shows: there is no significant difference, between sample group control: group 2 and 3 , 3 and 5, 4 and 8, 4 and 9, and 6, 5 and 8, 5 and 9,6 and 9, 8 and 9. On table 2 shows that all control groups have significant difference toward group 1 (control groups). It is means that duration of lighting of resin modified glass ionomer cement with various electric voltage input will influence the value of surface hardness.

\section{DISCUSSION}

Table 1 show that the input of voltage of exposure is lower resulting in the decrease of surface hardness of resin modified glass ionomer cement. The result of this is similar to the previous study suggests that the decrease of surface hardness of resin modified glass ionomer cement due to the decrease of voltage in which would lower the output of visible light curing unit consequently the result of light intensity would also decrease. ${ }^{8}$ The decrease of light intensity would affect photo activation and polymerization and further it would directly affect the number of free radical which initiates the occurrence of polymerization. ${ }^{1,13}$ Excessive low light intensity might contribute the necessary level of energy formation in free radical formation would decrease as a result the polymerization process is not perfectly done. Inadequate polymerization would cause a part of monomer could not react to be polymer chain and it would increase residual monomer. The increase number of residual monomer would decrease the degree of polymerization and relative molecule mass consequently the mechanical properties would decrease and in this case the decrease of surface hardness would occur. ${ }^{14}$

Two-way ANOVA test result indicates that significant difference was found between the time of exposure and the surface hardness of resin modified glass ionomer cement. 
The prolong exposure time would increase the surface hardness of resin modified glass ionomer cement because the light energy which is needed to activate initiator during polymerization process would increase. ${ }^{15}$ The decrease of light energy would result the number of photons which initiate the formation of free radical would increase therefore the degree of polymerization and mechanic character i.e surface hardness would increase.

Table 2 shows that group of voltage of light exposure 220, 210 and 200 volt with exposure time 40 seconds comparing to 60 seconds, the surface hardness value of resin modified glass ionomer cement statistically is not significantly different, in this case it might be due to the addition of resin in resin modified glass ionomer cement is relatively small about HEMA 5-15\%. In relatively small amount of resin, even though the time of exposure is prolonged from 40 seconds to 60 seconds the increase of surface hardness is not significantly different. The result of this study is similar to previous study which stated that low degree of polymerization was possibly caused by the small amount of resin. Further it was stated that resin polymerization in resin modified glass ionomer cement might be affected by acid-base reaction. ${ }^{16}$ During the process of powder and liquid resin modified glass ionomer cement were mixed, the acid-base reaction would immediately occur similarly to conventional glass ionomer cement. A part of cement which reacted acid-base was expected to inhibit polymerization process by visible light, therefore even though the time of exposure was prolonged from 40 to 60 seconds with the same voltage, it will not show significant increase of surface hardness of resin modified glass ionomer cement.

Light intensity produced by visible light curing could affect the depth and the time which is need for complete polymerization in composite resin. ${ }^{17}$ The result of this study shows that to prolong the time of exposure until 60 seconds with low voltage (200 and 210 volt) cannot increase the surface hardness of resin modified glass ionomer cement similar to surface hardness of control group. This condition would show that light intensity has more essential role in activating light initiator found in light modified glass ionomer cement. Inadequate light intensity due to low voltage (200 and 210 volt) could not activate optimally photo initiator material of resin modified glass ionomer cement therefore the polymerization is not as good as voltage of light exposure 200 volt.

Control group produced surface hardness of resin modified glass ionomer cement: 36.11 VHN. The result of this study is similar to the previous study which stated that resin modified glass ionomer cement with time of exposure 60 seconds produced surface hardness 36.2 VHN. ${ }^{18}$ The sample group with input 200 volt and time of exposure 60 seconds produced surface hardness of resin modified glass ionomer cement 27.55 VHN. The result of this study shows that time of exposure was prolonged until 60 seconds with low voltage input could not produce surface hardness of resin modified glass ionomer cement similar to control group.

The conclusion is the prolong of exposure time from 20 seconds to 40, 60 seconds in all voltage input can increase surface hardness of resin modified glass ionomer cement.

\section{REFERENCES}

1. Anusavice. Phillips' science of dental materials. $11^{\text {th }}$ ed. St Louis: WB Saunders Co; 2003. p. 96-8, 399-417, 482-4.

2. Mount GJ, Hume WR. Preservation and restoration of tooth structure. London, Philadelphia, St louis: Mosby Co; 1998. p. 55-105, 196-7.

3. Abate PF, Polack MA, Macchi RL. Barcoll hardness of resinmodified glass ionomer cements and a compomer. Quint Int 1997; 28:345-8.

4. Craig RG, Powers JM. Restorative dental materials. $11^{\text {th }}$ ed. St. Louis, London, Philadelphia: Mosby Co; 2002. p. 249-51, 212-7, 614-8.

5. Van Noort R. Introduction of dental materials. $2^{\text {nd }}$ ed. Edinburgh, London, New York Mosby Co; 2002. p. 124-46.

6. Ellyza H. Tinjauan terhadap suatu material restorasi: resin-modified glass ionomer. J Ked Gigi UI 1997; 4:468-78.

7. Budi SL. Pengaruh tegangan listrik, intensitas sinar dan waktu penyinaran terhadap kekerasan permukaan resin komposit sinar tampak. Tesis. Surabaya: Pascasarjana Universitas Airlangga; 1993. p. 42-64.

8. Titien HA. Pengaruh penurunan tegangan listrik penyinaran pada semen ionomer gelas modifikasi resin terhadap kekerasan permukaan. Majalah Kedokteran Gigi (Dent J) 2003; 36:143-6.

9. Marais JT, Dannheimer MF, Germishuys PJ, Borman JW. Depth of cure of light-cured composite resin with light-curing units of different intensity (Abstract). J Dent Assoc S Afr 1997; 52:403-7.

10. Nirawati P. Daya serap air dan kelarutan garam Na pada semen perekat ionomer gelas yang mendapat tekanan dan tidak mendapat tekanan. Thesis. Surabaya: Universitas Airlangga Indonesia. 2000; p. 22-4.

11. Ribeiro AP, Serra MC, Paulillo LAMS, Rodrigues CA. Effectiveness of surface protection for resin-modified glass-ionomer materials. Quint Int 1999; 30:427-31.

12. Anita Y. Pengaruh jarak dan lama penyinaran lampu penerang dental unit terhadap sifat fisik, mekanik dan kimia resin komposit sinar tampak. Thesis. Surabaya: Universitas Airlangga Indonesia. 1995; p. 41-3.

13. Fan PL, Wozniak WT, Reyes WD, Stanford JW. Irradiance of visible light-curing unit and voltage variation effect. JADA 1987; 115: 442-5.

14. Ruslan E. Pengaruh suhu dan lama penyimpanan resin komposit terhadap sifat kimia, sifat mekanik dan biokompatibilitas. Dissertation. Surabaya: Universitas Airlangga Indonesia.1993; p. 140-3.

15. Sakaguchi RL, Douglas WH, Peter MCRB. Curing light performance and polymerization of composite restorative materials. J Dent 1992; 20:183-8.

16. Ikeda K, Fujishima A, Yamamoto M, Inoue M, Suzuki M, Miyazaki T, Sasa R. Measurment of degree of cure for resin-modified glass ionomer cements by IR Spectroscopic Analysis. Dent in Japan 2002; 38:95-100.

17. Poulos JG, Styner DI. Curing lights: Changes in intensity output with use over time. Gen Dent (Abstract) 1997; 45:70-3. 